\title{
ROQUE JOAQUÍN ALCUBIERRE, REIVINDICADO
}

\author{
Pablo Huerga Melcón
}

Universidad de Oviedo

http://dx.doi.org/10.5209/NOMA.55014

Resulta apasionante indagar en los avatares históricos y las circunstancias que permitieron recuperar el manuscrito completo del poema filosófico más bello de la literatura latina y una de las obras de mayor influencia cultural. Nos referimos al poema de Lucrecio, De rerum natura. De la vida de Lucrecio se sabe lo que dejó escrito San Jerónimo en una interpolación que hace al Cronicón de Eusebio, tomada, a su vez, de Suetonio. Aunque algunos datos sean discutibles, nació sobre el 94 antes de Cristo y murió con 43 años en el año 51 antes de Cristo. Su obra, publicada póstumamente, pudo ser preparada por Cicerón, de quien era contemporáneo y conocido. Mientras que la locura que se le suele atribuir, a cuenta de un filtro amoroso, no parece plausible. Se dice que se suicidó. No faltan quienes niegan todo valor a los datos de San Jerónimo, como hace Luciano de Canfora. Su obra, sin embargo, tal vez condenada al olvido como la propia obra de Epicuro de cuyos 300 rollos de papiro, según Diógenes Laercio, se conservan solamente algunos fragmentos, se ha conservado, como si hubiera de cumplir el elogio que le dedicó Ovidio cuando dijo que el poema de Lucrecio durará tanto como el mundo.

La historia de la recuperación del texto de Lucrecio es digna de ser contada y los filólogos y traductores lo han hecho con esmero. Dos estirpes de manuscritos se conservan, ambas procedentes de una copia del siglo IX. Una de ellas, que incluye dos manuscritos (el Oblongus y el Quadratus), se encuentra en la Universidad de Leyden, procedente de la biblioteca de Gerardo Vossius; la otra, procedente de Italia, es la que se tomó como base para todas las publicaciones del poema hasta el siglo XIX. Fue Poggio Bracciolini el primero que lo puso en circulación habiéndolo descubierto, mientras realizaba entre 1414 y 1418 pesquisas en distintos monasterios y abadías europeos con el fin de recoger textos latinos y llevarlos a Florencia, aprovechando el viaje que como secretario apostólico del entonces (anti)papa Juan XXIII hubo de hacer al concilio de Constanza, donde finalmente este papa terminaría siendo encarcelado. Lo curioso es que Poggio tampoco menciona el lugar exacto (sólo dice "locus satis loginquus") donde se encontró con el manuscrito De rerum natura que mandó copiar. Copiada a su vez por su amigo Niccolo Niccoli, hoy es la copia más antigua que se conserva de la estirpe italiana y está recogida en la Biblioteca Laurenciana de Florencia. Greenblatt supone que ese misterioso lugar sería la Abadía de 
Fulda, en el centro de Alemania, otros apuntan a la Biblioteca de San Martín de Maguncia, mientras que José Ignacio Cirvelo Borge, discípulo del humanista Eduard Valentí Fiol, cree que pudo ser la biblioteca de la Abadía de Murbach, en Alsacia, donde hay constancia de que en el siglo IX había un manuscrito del De rerum natura. El caso es que el Oblongus de Leyden procede también de Fulda y Maguncia, lo que ha suscitado la opinión de Diels, que afirma que Poggio pudo tomar su copia de alguna de las de Leyden; en cuyo caso, las dos estirpes de manuscritos serían en realidad una única estirpe. Poggio encontró también en dicha biblioteca otro importante texto, el poema épico más largo de la literatura latina, Púnicas, de Silio Itálico, que nos dio la pista sobre la leyenda del rey Astur, el cochero del sobrino de Príamo, y héroe de Troya muerto por Aquiles, Memnón. Según la leyenda, Astur habría dado el nombre a Asturias, después de arribar a nuestras costas por la playa de la Griega, como nuestro particular Eneas (publicamos un artículo en La Nueva España hace dos años sobre este tema. Púnicas podría ser considerado el primer poema épico español y Silio Itálico, nuestro Homero.)

La historia de Lucrecio, que vivió "cuando los dioses habían dejado de existir y Cristo aún no había nacido", como decía Gustave Flaubert; la propia historia de su manuscrito y la del humanista rastreador Poggio Bracciolini, así como la enorme influencia que dicho texto tendría en la revolución científica, eran desde luego un argumento magnífico para un ensayo de historia y filosofía de la ciencia. Y eso es precisamente lo que aprovechó con acierto Stephen Greenblatt, en su interesante libro, El giro. De cómo un manuscrito olvidado contribuyó a crear el mundo moderno, publicado en Barcelona por la editorial Cátedra en el año 2012. El título hacer referencia a la teoría del Clinamen, que es el punto en el que se diferencian particularmente los dos sistemas atomísticos de la antigüedad, el de Demócrito y Leucipo y el de Epicuro y Lucrecio. Hay que decir que este tema dio argumento para la tesis doctoral de Carlos Marx. Sin embargo de lo cual, Stephen Greenblatt, embriagado por la exuberancia del tema escogido, comete una falta de objetividad flagrante y calumniosa que debe ser contestada.

Una de las numerosas curiosidades involucradas en la historia de Lucrecio y su De rerum natura, tiene que ver con los hallazgos de la Villa de los Papiros, en el yacimiento arqueológico de Herculano. En 1987, Tommaso Starace descubrió que uno de los rollos de papiro era una copia del poema de Lucrecio, juna copia del siglo I! Greenblatt aprovecha entonces para entrar de lleno en los detalles de la excavación y su historia. La Villa de los Papiros habría pertenecido a Lucio Calpurnio Pisón Cesonino, suegro de Julio César, y albergaba en su biblioteca una importante colección de obras epicureístas, y una disposición aristocrática hacia el placer y el retiro espiritual inspirada en algunos de los preceptos de la doctrina epicúrea. 
Pero cuando Greenblatt pretende remitirse a los orígenes de los trabajos arqueológicos que permitieron estos importantes descubrimientos, suelta el siguiente párrafo en la página 56:

Los trabajos de exploración, que continuaron cuando Nápoles pasó a manos de los Borbones, fueron extraordinariamente toscos, menos parecidos a una investigación arqueológica que a un robo continuado con efracción. El responsable de las obras fue durante más de una década un ingeniero militar español, Roque Joaquín Alcubierre, que, al parecer, trató el tugar como si fuera un basurero fosilizado en el que había sido enterrado un botín infinito ("Este individuo", comentó cierto personaje de la época, escandalizado por la enormidad del daño gratuito que estaba haciéndose, "tiene tanto que ver con las antigüedades como la luna con los cangrejos".) Los operarios se dedicaban a cubrir zanjas en busca de estatuas joyas, mármoles preciosos y otros tesoros más o menos conocidos, que encontraban en abundancia y entregaban en caótica profusión a sus regios señores.

En 1750 a las órdenes de un director nuevo, los exploradores empezaron a poner un poco más de cuidado en su labor.

Indigno de su autor, este tipo de descalificaciones groseras abundan en la historiografía porque el pasado de España ya no merece ningún respeto, ni siquiera para los españoles. No obstante, era necesario revisar estos datos y comprobar efectivamente lo que aquí se afirma de un modo tan imprudente. Un somero repaso a la bibliografía sobre el tema en artículos y libros nos revela una situación radicalmente opuesta a esta calumnia.

Alcubierre era un ingeniero militar español nacido en Zaragoza en 1702 , y muerto en Nápoles en 1780, con el título de Mariscal de Campo de Nápoles. Encargado de unas obras por parte de la corte de Nápoles en una propiedad del rey, se dio cuenta del tesoro que albergaba el subsuelo y solicitó y convenció a Carlos III para excavar Herculano, Pompeya, Estabia, la villa de Polión en Sorrento, Capri, Pozzuoli y Cumas. Las obras comenzaron en 1738 y se prolongaron durante toda su vida. Consciente de la importancia de los yacimientos, aplicó técnicas mineras para no dañar la estructura de los edificios descubiertos, cartografió todas las ciudades con sumo cuidado y precisión. Dice María del Carmen Alonso Rodríguez, en un ensayo sobre el tema:

"Ias excavaciones arqueológicas estuvieron siempre dirigidas por ingenieros militares capaces de topografiar adecuadamente tanto las galerías como el exterior y de elaborar planos e informes que documentan la marcha de los trabajos... Estamos pues ante uno de los 
primeros ejemplos de la recogida de datos de campo de manera ordenada en los estudios arqueológicos".

Dirigió las obras con el apoyo directo de quien sería después Carlos III de España, que organizó en Nápoles lo que hoy es el voluptuoso Museo Arqueológico, enriquecido con la fastuosa colección Farnesse, propiedad del rey, que mandó traer desde Parma. Los materiales recuperados se organizaron por categorías, para ser contemplados por el público. Los descubrimientos se recogían en una publicación específica editada por orden real. Carlos III puso además especial cuidado en el estudio de los rollos de papiro que en 1753 fueron encontrados en la villa de los Papiros. Hizo venir desde la Biblioteca Vaticana al experto Antonio Piaggio que inventó una máquina para desenrollar estos manuscritos sin estropearlos más de lo que estaban, e identificarlos. La dedicación y el respeto al trabajo arqueológico sitúa esta empresa en el primer lugar de la historia de la arqueología moderna y sería el modelo, por ejemplo, que luego se siguió para la recuperación del sitio arqueológico de la ciudad maya de Palenque, óbra también realizada por el empeño del rey Carlos III.

Félix Fernández Murga, en un libro dedicado al papel de Carlos III en estas excavaciones, dice:

"Empresa arqueológica única y sin precedentes que bien puede considerarse como el primer intento de excavación organizada y metódica que se conoce. En ningún lugar de la Europa ilustrada se emprendieron los trabajos con tantos medios y tanta voluntad de servir a la ciencia, y al conocimiento de la antigüedad como en el caso de estas ciudades [...] Pero al mismo tiempo, con el Museo Ercolanese nace el primer museo monográfico dedicado a la arqueología y el primero que se monta en función de unas excavaciones y de sus necesidades".

Comparado con esto, nos preguntamos cómo habría que explicar lo que hizo, por ejemplo, Lord Elgin con los mármoles del Partenón, quien sólo veinte años después de los acontecimientos antes referidos, esquilmó y destrozó de modo irreversible el famoso friso del Partenón, cortando piezas únicas, y llevándoselas para Londres. ¿A Acaso eso es arqueología y no rapiña? ¿̇Y Napoleón en su conquista de Egipto? ¿Qué es el Museo de Pérgamo? El museo de Nápoles se realizó en el mismo lugar de las excavaciones y con el mayor respeto a lo que allí se encontraba. Creemos que este detalle es un ejemplo práctico de la diferencia entre Imperio generador e Imperio depredador, establecida por Gustavo Bueno en su libro España frente a Europa. 
El misterioso erudito que cita Greenblatt insultando a Alcubierre no es otro que el esforzado historiador del arte Winkelmann, que estaba "echando chispas" porque Carlos III no le dio permiso para acceder a las excavaciones, como hubiera sido su deseo. Este asunto del permiso tenía, por supuesto, razones geopolíticas de suma importancia. El Imperio Español estaba siendo acosado por las nuevas potencias europeas, y ninguno de estos eruditos y científicos iba en "búsqueda desinteresada de la verdad". El discurso positivista de la ciencia por la ciencia sólo sirve para ocultar intereses espurios. Y no hay mejor prueba que el caso del famoso científico alemán, Alexander Humboldt, el creador del Mito de la Naturaleza. A Humboldt se le permitió imprudentemente por parte de Carlos IV viajar a Sudamérica, donde, después de tres años de permanencia y habiendo viajado por Venezuela, Colombia, Perú, Chile, Ecuador México, etc., no tuvo otra ocurrencia que ir directamente a visitar al gran Thomas Jefferson, presidente de EEUU, para darle buena cuenta durante varias semanas, del estado de las colonias españolas, sobre todo aquellas de la Nueva España que serían posteriormente arrebatadas por EEUU, y que Humboldt describió para el admirado presidente con todo detalle. Esto lo cuenta alborozada otra historiadora anglosajona, Andrea Wolf, en un libro reciente titulado La invención de la Naturaleza. El nuevo mundo de Alexander von Humboldt, editado en Madrid por Taurus, que también carga las tintas contra España de modo gratuito. Es curioso, no obstante, que Jefferson sea el último epicúreo citado en el libro de Greenblatt.

Este poco profesional tratamiento realizado por quienes dan muestras de ser buenos científicos e investigadores, debe ser analizado en términos gnoseológicos. Apuntamos aquí meramente la siguiente hipótesis: la precaria situación de España como nación política, su debilidad estructural provocada por años de dejadez y políficas imprudentes, hace que los historiadores situados en el vórtice del proyecto globalizador comiencen a desestimar el papel que desde la nueva historiografía cabe atribuir a un territorio que ya puede comenzar a dejar de considerarse como término -sujeto activo- del campo gnoseológico de la Historia. Sólo así puede entenderse que Andrea Wolf despache la Guerra de Independencia en España con esta frase brutal (pág. 185):

"Al terminar 1813, el ejército británico, bajo el mando del duque de Wellington, había expulsado a los franceses de España".

En Gijón, a 11 de diciembre de 2016 